\title{
Prevalence of cigarette smoking and its predictors among school going adolescents of North India
}

\author{
Durgesh Thakur, Anmol Gupta, Anita Thakur, Salig Ram Mazta, Deepak Sharma'
}

\begin{abstract}
Background: Cigarettes smoking is a common mode of consuming tobacco in India. This habit usually starts in adolescence and tracks across the life course. Interventions like building decision making skills and resisting negative influences are effective in reducing the initiation and level of tobacco use. Aims and Objectives: The purpose of this study was to assess the prevalence of adolescent current cigarette smoking behavior and to investigate the individual and social factors, which influence them both to and not to smoke. Methodology: A cross-sectional study was carried out among school going adolescents in Shimla town of North India.After obtaining their written informed consent, a questionnaire was administered. Results: The overall prevalence of current cigarette smoking was I I.8\%. The binary logistic regression model revealed that parents' and peers' smoking behavior influence adolescent smoking behavior. Individual self-harm tendency also significantly predicted cigarette smoking behavior. Parental active participation in keeping a track of their children's free time activities predicted to protect adolescents from taking this habit. Conclusion: Our research lends support to the need for intervention on restricting adolescents from taking up this habit and becoming another tobacco industries' addicted customer. Parents who smoke should quit this habit, which will not only restore their own health, but also protect their children. All parents should be counseled to carefully observe their children's free time activities.
\end{abstract}

Key words: Adolescent, smoking, social environment

\section{Introduction}

Tobacco smoking is the biggest public health threat of the current era. Worldwide, smoking-related diseases kill an estimated 4 million people every year. This number is predicted to rise to a staggering 10 million a year over the next two decades. There is an overwhelming body of evidence of increased cancer risk in cigarette smokers. ${ }^{[1,2]}$

Adolescence is a developmental period where behavior is influenced by emotional and social functions. Tobacco companies use sophisticated marketing campaigns to attract people to initiate this habit early. This is precisely based on the premise that, an adolescent once initiated into tobacco use will continue using it lifelong, with very low quit rates. For the tobacco companies, this translates into lifetime revenues, while on the contrary for adolescents it leads to chronic illnesses later in life. ${ }^{[3,4]}$ The rate of adolescent addiction to cigarettes is high in India. According to Global Adult Tobacco Survey 2009, India, more than half of the smokers initiate smoking in their

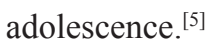

Effort to prevent adolescent smoking focuses on building their individual resistance to social influences. ${ }^{[6]}$ The current study aimed to assess the prevalence of current adolescent cigarette smoking and to investigate the individual and social factors, which influence them both to and not to smoke.

\section{Methodology}

A cross-sectional study was conducted among school going adolescents of Shimla town, capital city of Himachal Pradesh. This town has ten government senior secondary schools. The study was conducted during the period from September 2012 to November 2013. In the absence of previous data on cigarette smoking among adolescents in the study area, an estimated prevalence of $50 \%$ was used to arrive at the sample size of $384\left(n=[1.96]^{2} \times 0.50 \times 0.50 /[0.05]^{2}\right)$ considering $95 \%$ confidence level and \pm 0.5 precision. In order to compensate

\begin{tabular}{|c|c|}
\hline Access this article online & \multirow{2}{*}{$\begin{array}{l}\text { Departments of Community Medicine, Indira Gandhi } \\
\text { Medical College, Shimla, Himachal Pradesh, 'Post } \\
\text { Graduate Institute of Medical Education and Research, } \\
\text { Chandigarh, India } \\
\text { Correspondence to: Dr. Anmol Gupta, } \\
\text { E-mail: dranmol1964@gmail.com }\end{array}$} \\
\hline 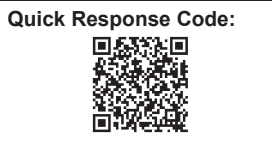 & \\
\hline Website: www.sajc.org & \\
\hline DOI: $10.4103 / 2278-330 X .142946$ & \\
\hline
\end{tabular}

for design defect, the required sample was multiplied by 2 . For student nonresponse/absenteeism the sample size was a further increase by $20 \%$. Thus, the final arrived sample size was 720 .

Stratified cluster sampling was used to draw a representative sample of students from grades $9^{\text {th }}, 10^{\text {th }}, 11^{\text {th }}$ and $12^{\text {th }}$ of the schools. Each class room was considered to be a cluster (38 clusters in 10 schools). From these, 21 classes (primary sampling unit) were selected through probability proportionate to size sampling. In each class, 36 students were selected using simple random sampling to obtain the sample size of 720 .

Current cigarette smoker was defined as a student who had smoked cigarettes on one or more days in the preceding month (30 days) of the survey. The individual factors included questions on "feeling sad", self-body image consciousness", and "self-harm". The social factors, included questions on family (sample question: "Do your parents know what you are doing in the free time") friends (sample question: "Do your friends smoke?") and school environment (sample question: "Are you happy regarding school relation with your teacher").

Formal approval was obtained from the State Education Department of Himachal Pradesh and Principals of the selected schools. Informed written consent was obtained from all the study participants and their parents/guardians. Collected data was analyzed using Epi-info software 6.04 for DOS (Centre for Disease Control, Atlanta). Possible predictors of adolescent smoking behaviors' were identified using a logistic regression model.

\section{Results}

The study sample consists of 720 adolescents of which $367(51 \%)$ were males and $353(49 \%)$ were females. Overall, $216(30 \%)$ were enrolled in $9^{\text {th }}$ grade, $216(30 \%)$ in $10^{\text {th }}$ grade, $144(20 \%)$ in $11^{\text {th }}$ grade and $144(20 \%)$ in $12^{\text {th }}$ grade respectively. The mean age of the study population was 15.4 years (standard deviation $[\mathrm{SD}]=1.4$ years).

Eighty-three out of 720 students $(11.8 \%)$ were currently smoking cigarettes. The mean age of initiation of smoking was 13.4 years $(\mathrm{SD}=1.9$ years). More adolescent boys $(22 \%)$ when compared to girls $(1 \%)$ were cigarette smokers $(P<0.001)$. With increasing age the prevalence of smoking increased. It was $6.4 \%$ in adolescent aged 14 years and increased to $26.3 \%$ in adolescents aged 19 years [Table 1]. 
In the binary logistic model, smoking family member (adjusted odds ratio $[\mathrm{AOR}]=2.1$, confidence interval $[\mathrm{CI}]$ $=1.1-3.8)$ and smoking friends $(\mathrm{AOR}=4.9, \mathrm{CI}=2.5-9.5)$ and self-harm $(\mathrm{AOR}=2.3, \mathrm{CI}=1.2-4.4)$ were significant risk factors of adolescent smoking behavior. Parental active participation in keeping a track of their children's free time activities can protect adolescents from starting to smoke $(\mathrm{AOR}=0.4, \mathrm{CI}=0.2-0.7)[$ Table 2$]$.

\section{Discussion}

In this study, the prevalence of current cigarette smoking at $12 \%$ was higher against the national average of $6.4 \%$ (Global Youth Tobacco Survey [GYTS] India 2009) and the state prevalence of 4\% (GYTS Himachal Pradesh 2004). ${ }^{[7,8]}$ The higher prevalence of smoking in our study could be a warning sign of the increasing attitude toward smoking epidemic among adolescents. We observed that the cigarette smoking generally increased with increasing age. The may be explained by the fact that increasing age in the adolescent period is more susceptible to experimentation of risky behaviors like smoking tobacco. Further, in the present study smoking was more among males as compared to females. This observed gender differences can be attributed to societal tolerance attitudes towards male smoking vis-a-vis female smoking in India.

The logistic regression model revealed that having a cigarette smoker at home significantly increased the likelihood of taking up smoking among adolescents. A possible explanation of this may be the fact that adolescents tend to learn by imitation. This tendency means that they will imitate both positive and unhealthy behaviors. Thus, the parental smoking behavior may outweigh adolescent's knowledge of harms of smoking and they resort to this habit. Similar to our observation, studies done by Kelishadi et al. in Iranian adolescents and Shashidhar et al. in Indian adolescents have reported this relationship. ${ }^{[9,10]}$

Self-harm is primarily a way to cope and deal with feelings that are distressing. In our study we observed that the self-harm tendency was associated with adolescents taking up cigarette smoking behavior. This may precisely be due to the fact that the self-harm experience may generate many difficult feelings and emotions in them like guilt, self-hatred, anger and thus they start smoking. However, eventually this may exacerbate such children's future self-harming behavior. Furthermore, we observed that parental monitoring of child's free time activity was a significant protective factor against adolescent's smoking behavior. Parents thus need to take the responsibility to constantly monitor their children activities and control their whereabouts. ${ }^{[11,12]}$

A limitation of this study is the use of self-reported survey, which may have resulted in reporting bias. However, the study investigators ensured that privacy of study participants and thus reliability of the responses. Another limitation is related to the cross-sectional design of the study and thus temporality between predictive factors and smoking aspects cannot be assured.

\section{Conclusion}

To conclude, the role of parents in fighting this negative habit remains very important. They should motivate their children not to be tempted by peer pressure, educate them of the ill health effects of smoking and monitor their free time activities. All those children whose parents smoke must be an offer to quit
Table 1: Sociodemographic correlates of adolescent cigarette smokers in Shimla city of North India

\begin{tabular}{lcc}
\hline Factors & Cigarette smokers (\%) & Significance \\
\hline Age (years) & & \\
$14(n=233)$ & $15(6.4)$ & $\chi^{2}=17.3$ \\
$15(n=153)$ & $19(12.4)$ & $\mathrm{df}=5, P=0.004$ \\
$16(n=157)$ & $15(9.6)$ & \\
$17(n=121)$ & $22(18.2)$ & \\
$18(n=37)$ & $7(18.9)$ & \\
$19(n=19)$ & $5(26.3)$ & \\
Grade & $26(12.0)$ & $\chi^{2}=3.5$ \\
$9^{\text {th }}(n=216)$ & $18(8.3)$ & $\mathrm{df}=3, P=0.320$ \\
$10^{\text {th }}(n=216)$ & $20(13.8)$ & \\
$11^{\text {th }}(n=144)$ & $19(13.2)$ & $\chi^{2}=69.5$ \\
$12^{\text {th }}(n=144)$ & & $\mathrm{df}=1, P=0.000$ \\
Gender & $78(21.3)$ & \\
Male $(n=367)$ & $5(1.4)$ & $\chi^{2}=2.7$ \\
Female $(n=353)$ & & $\mathrm{df}=1, P=0.09$ \\
Mothers education & $70(12.6)$ & $\chi^{2}=2.1$ \\
Up to $10^{\text {th }}(n=552)$ & $13(7.7)$ & $\mathrm{df}=1, P=0.15$ \\
$>10^{\text {th }}$ standard $(n=168)$ & & \\
Fathers education & $45(13.4)$ & \\
Up to $10^{\text {th }}(n=335)$ & $38(9.8)$ & \\
$>10^{\text {th }}$ standard $(n=385)$ & & \\
\hline
\end{tabular}

Table 2: Predictors for cigarette smoking among school going adolescents in Shimla city of North India

\begin{tabular}{|c|c|c|}
\hline Variable & OR & $95 \% \mathrm{CI}$ \\
\hline \multicolumn{3}{|l|}{ Social environment factors } \\
\hline \multicolumn{3}{|l|}{ Family } \\
\hline $\begin{array}{l}\text { Parents listen to children and take their feelings } \\
\text { seriously? }\end{array}$ & 0.8 & $0.4-1.7$ \\
\hline Parents know their childrens' friends? & 1.6 & $0.8-3.3$ \\
\hline Parents know what their child does in free time?* & 0.4 & $0.2-0.7$ \\
\hline Worrying issue in the family? & 1.5 & $0.8-2.7$ \\
\hline Family member smokes?* & 2.1 & $1.1-3.8$ \\
\hline \multicolumn{3}{|l|}{ Friends } \\
\hline Close friends smoke?* & 4.9 & $2.5-9.5$ \\
\hline \multicolumn{3}{|l|}{ School } \\
\hline Happy with your school relation with teachers? & 0.9 & $0.4-1.9$ \\
\hline $\begin{array}{l}\text { Classmates kind and helpful to you most of the } \\
\text { times? }\end{array}$ & 0.7 & $0.3-1.3$ \\
\hline Grades this year worse than last year? & 1.7 & $0.9-3.2$ \\
\hline \multicolumn{3}{|l|}{ Individual factors } \\
\hline In the past year, tried to control your weight? & 1.3 & $0.7-2.4$ \\
\hline Concerned about the physical appearance? & 0.8 & $0.4-1.6$ \\
\hline When you get angry, do you hurt yourself?* & 2.3 & $1.2-4.4$ \\
\hline
\end{tabular}

and fathers education. $\mathrm{OR}=\mathrm{Odds}$ ratio, $\mathrm{CI}=$ Confidence interval, * Significant at $P<0.05$

and thus become "anti-smoking role models". Further, smoke free laws in India should be widened beyond their traditional focus on enforcing the ban. As smoking is individual behavior influenced by individual and societal influences, efforts to foster positive long-term interventions focused at the individual, family, and community levels should be the focus of the program and policy makers in India.

\section{References}

1. Tobacco free initiative (TFI): Why is tobacco a public health priority? Available from: http://www.who.int/tobacco/health_priority/en. [Last accessed on 2014 Feb 02].

2. Health effects of smoking among young people. Available from: http://www.who.int/tobacco/research/youth/health_effects/en/. [Last accessed on 2014 Jan 26].

South Asian Journal of Cancer October-December 2014 Volume 3 Issue 4 
3. Forman SF, Emans SJ. Current goals for adolescent health care. Hosp Phys 2000;36:27-42.

4. Neinstein LS. Adolescent Health Care: A Practical Guide. $4^{\text {th }}$ ed. USA: Lippincott Williams and Wilkins; 2002.

5. GATS India report. Ministry of Health and Family Welfare. Available from: http://www.mohfw.nic.in/WriteReadData/I892s/1455618937GATS\%20 India.pdf. [Last accessed on 2014 Feb 02].

6. Cambell TL, Bray JH. The family influence on health. In: Robert ER, editor. Textbook of Family Practice. $6^{\text {th }}$ ed. Pennsylvania: W B Saunders Company; 2002. p. 31-41.

7. World Health Organization (SEARO): GYTS fact sheets and reports for India 2000-2006. Available from: http://www.searo.who.int/en/ Section 1174/Section2469/Section2480_14169.htm. [Last accessed on $2014 \mathrm{Feb}$ 02].

8. Sinha DN. Tobacco control in schools in India (India Global Youth Tobacco Survey and Global School Personnel Survey, 2006). New Delhi, India: Ministry of Health and Family Welfare; 2006.

9. Kelishadi R, Ardalan G, Gheiratmand R, Majdzadeh R, Delavari A, Heshmat R, et al. Smoking behavior and its influencing factors in a national-representative sample of Iranian adolescents: CASPIAN study. Prev Med 2006;42:423-6.

10. Shashidhar A, Harish J, Keshavamurthy SR. Adolescent smoking: A study of knowledge, attitude and practice in high school children, pediatric on call child health care. Available from: http://www. pediatriconcall.com/fordoctor/Medical_original_. [Last accessed on 2014 Feb 02].

11. Reda AA, Moges A, Yazew B, Biadgilign S. Determinants of cigarette smoking among school adolescents in eastern Ethiopia: A cross-sectional study. Harm Reduct J 2012;9:39.

12. Muttappallymyalil J, Divakaran B, Thomas T, Sreedharan J, Haran JC, Thanzeel M. Prevalence of tobacco use among adolescents in north Kerala, India. Asian Pac J Cancer Prev 2012;13:5371-4.

How to cite this article: Thakur D, Gupta A, Thakur A, Mazta SR, Sharma D. Prevalence of cigarette smoking and its predictors among school going adolescents of North India. South Asian J Cancer 2014;3:193-5.

Source of Support: Funding from NRHM, Himachal Pradesh, India. Conflict of Interest: None declared.

\section{Author Help: Online submission of the manuscripts}

Articles can be submitted online from http://www.journalonweb.com. For online submission, the articles should be prepared in two files (first page file and article file). Images should be submitted separately.

\section{1) First Page File:}

Prepare the title page, covering letter, acknowledgement etc. using a word processor program. All information related to your identity should be included here. Use text/rtf/doc/pdf files. Do not zip the files.

\section{2) Article File:}

The main text of the article, beginning with the Abstract to References (including tables) should be in this file. Do not include any information (such as acknowledgement, your names in page headers etc.) in this file. Use text/rtf/doc/pdf files. Do not zip the files. Limit the file size to $1024 \mathrm{~kb}$. Do not incorporate images in the file. If file size is large, graphs can be submitted separately as images, without their being incorporated in the article file. This will reduce the size of the file.

3) Images:

Submit good quality color images. Each image should be less than $\mathbf{4 0 9 6} \mathbf{~ k b ~ ( 4 ~ M B ) ~ i n ~ s i z e . ~ T h e ~ s i z e ~ o f ~ t h e ~ i m a g e ~ c a n ~ b e ~ r e d u c e d ~ b y ~ d e c r e a s i n g ~ t h e ~}$ actual height and width of the images (keep up to about 6 inches and up to about $1800 \times 1200$ pixels). JPEG is the most suitable file format. The image quality should be good enough to judge the scientific value of the image. For the purpose of printing, always retain a good quality, high resolution image. This high resolution image should be sent to the editorial office at the time of sending a revised article.

4) Legends:

Legends for the figures/images should be included at the end of the article file. 